\title{
МОРФОФУНКЦІОНАЛЬНА ХАРАКТЕРИСТИКА ПЕЧІНКИ ЩУРІВ У РАННІ ТЕРМІНИ РОЗВИТКУ СТРЕПТОЗОТОЦИНОВОГО ЦУКРОВОГО ДІАБЕТУ З ВИКОРИСТАННЯМ КЛАСТЕРНОГО АНАЛІЗУ
}

\author{
Жураківська О.Я., Боднарчук Ю.В., Костіцька I.О., Кіндратів Е.О., Андріїв А.В., \\ Жураківський В.М., Міськів В.А., Перцович В.М., Саган Н.Т., Іванців О.Р. \\ Івано-Франківський національний медичний університет, м. Івано-Франківськ, Украӥна \\ zhurakivska.o.ya@gmail.com
}

\begin{abstract}
Медико-соціальна проблема ЦД полягає в тому, що він є одним із найпоширеніших ендокринних захворювань у світі, а його ускладнення призводять до втрати працездатності, інвалідності та смерті паціентів [1]. Одним із таких ускладнень є діабетична гепатопатія, яка, за даними різних авторів, діагностуеться у 33-88\% хворих [2]. Субклінічний перебіг останньої веде до того, що специфічні ознаки ураження гепатобіліарної системи (гіркота в роті, важкість у правому підребер'ї, субіктеричність слизових оболонок, диспепсичні явища) діагностують лише у $18-33 \%$ хворих, однак, реальна цифра сягае $24-88 \%$ хворих на ЦД [3]. Незважаючи на велику кількість наукових досліджень, що присвячені ви-
\end{abstract}

вченню впливу ЦД на печінку [4-6], залишається остаточно нез'ясованим питання, яким чином гіперглікемія впливає на морфоффункціональний стан гепатоцитів різних зон печінкової часточки при даному захворюванні та як порушуеться їх функція при цьому.

Окремі автори вивчаючи зміни в печінці 12-ти місячних щурів при ЦД проводили порівняння середніх значень показників гепатоцитів в печінковій часточці $[4,5]$, без врахування відмінностей морфологічної будови у різних зонах, що не дає можливості пов'язати морфологічні зміни в клітинах із функціональною неоднорідністю різних зон печінкової часточки. Слід зазначити, що в жодних наукових роботах

* Роботу виконано в межах дисертаційної роботи відповідно до плану Івано-Франківського національного медичного університету і е фрагментом двох науково-дослідних робіт кафедри анатомії людини «Оптимізація комплексного лікування морфологічних ушкоджень травної, ендокринної та сечостатевої систем при цукровому діабеті» (номер держреєстрації 0113U000769), «Вікові особливості патоморфогенезу деяких органів нейроендокринної, серцево-судинної, травної та дихальної систем при цукровому діабеті» (номер держреєстрації 0116U003598).

Установою, що фінансуе дослідження, е МОЗ України.

Автори гарантують повну відповідальність за все, що опубліковано в статті.

Автори гарантують відсутність конфлікту інтересів і власної фінансової зацікавленості при виконанні роботи та написанні статті.

Рукопис надійшов до редакції 3.08.2020. 
при морфометричному дослідженні печінки не використано кластерного аналізу.

Зважаючи на вищевикладене, метою нашого дослідження було встановити особ- ливості морфофрункціональних змін печінки при експерименальному стрептозотоциновому ЦД (ЕСЦД) з використанням кластерного аналізу.

\section{МАТЕРІАЛИ І МЕТОДИ}

Для дослідження використали 22 статевозрілих щурів-самців лінії Вістар 12-ти місячного віку (180-220 г), які були поділені на 2 групи. У першу групу ввійшло 12 тварин, яким моделювали ЕСЦД одноразовим внутрішньоочеревинним введенням стрептозотоцину, попередньо розведеного в 0,1 М цитратному буфері з рH 4,5, із розрахунку 6 мг/100 г маси тіла. У другу (контрольну) групу ввійшло 10 тварин, яким в еквівалентній дозі внутрішньоочеревинно вводили 0,1 М цитратний буфер 3 pH 4,5. Рівень глюкози в крові тварин щоденно вимірювали вранці натще глюкометром "Accu-Chek Active» ("Roche Diagnostics GmbH», ФPH). Забір матеріалу здійснювали на 14-ту та 28-у добу від початку моделювання ЕСЦД. Під ефрірним наркозом проводили декапітацію з одночасним забором крові в пробірку для біохімічних досліджень. Вміст HbA1c у крові визначали в сертифікованій лабораторії «Діамеб».

Дослідження активності АЛТ та АCT у сироватці крові (мкмоль / (год × мл) та гомогенатах печінки (мкмоль / (год × г) проводили в сертифікованій лабораторії «Центру біоелементології» Івано-Франківського національного медичного університету за методом Райтмана-Френкеля, використовуючи набір реактивів («Філісіт-Діагностика», Україна).

Експерименти на щурах проводили з дотриманням усіх етичних вимог та відповідно до положення Європейської конвенції про захист хребетних тварин, що використовуються для дослідних та інших наукових цілей (Страсбург, 1986), Директиви Ради Європи 86/609/СЕС (1986), Закону України «Про захист тварин від жорстокого поводження» від 15 грудня 2009 року та наказів МОЗ України № 690 від 23.09.2009 р., № 616 від 03.08.2012 р. (експертний висновок комісії з питань етики ДВНЗ «Івано-Франківський національний медичний університет», протокол № 104/18 від 25.10.2018 р.).
Для гістологічного та гістохімічного дослідження печінки використали забарвленням гематоксиліном та еозином, трихром за Массоном, за Шабадашем та суданом III. Для електронномікроскопічного дослідження шматочки печінки фіксували в $2 \%$ розчині чотириокису осмію, проводили та контрастували за загальноприйнятим методом. Вивчення матеріалу проводили на електронному мікроскопі ПЭМ-125 К при прискорювальній напрузі 75 кВ із наступним фротографруванням.

Для морфометричних досліджень використовували мікрофротографії гістологічних, гістохімічних та напівтонких зрізів, збережених у tif форматі. Морфометрію здійснювали за допомогою програми «ImagеЈ». Використовували такі методи статистичного аналізу [7]:

1) кластерний аналіз одноядерних гепатоцитів різних зон печінкової часточки (метод ієрархічної деревоподібної кластеризації Уорда (Ward's method) та метод K-means. Вимірювали всі одноядерні гепатоцити, що містилися в межах однієї печінкової часточки (площу профілю гепатоцитів, площу профілю ядер гепатоцитів та ядерно-цитоплазматичне співвідношення (ЯЦС)) і вказували належність до різних зон печінкової часточки (центральної, проміжної та периферичної). Перед застосуванням процедури ієрархічної кластеризації всі характеристики стандартизовували (від кожного вибіркового значення віднімалося їх середнє значення і різниця ділилася на вибіркове стандартне відхилення). Кластеризацію здійснювали з допомогою методу К-середніх кластерного аналізу. Цей метод базується на мінімізації суми квадратів відстаней між кожним спостереженням (гепатоцитом) та центром його кластера. Для порівняння середніх значень (стандартизованих 
величин між різними кластерами та контрольними показниками) використовували t-критерій. Щоразу, коли одержували p-value $(\mathrm{p})<0,05$, стверджували про статистичну достовірність різниці між заданими показниками;

2) порівняння розподілів (\% вміст) кластерів у кожній зоні (центральній, проміжній та периферичній) печінкової часточки проводили, використовуючи критерій Xi-квадрат аналізу таблиць спряженості. Критерій Пірсона вказує на належність цього кластеру до тіеї чи іншої зони у \% відношенні. Також \% вміст кластерів гепатоцитів визначали на кожен термін ЕСЦД. Для порівняння середніх значень стандартизованих характеристик між кластерами в кожній групі застосовано t-критерій Стьюдента для незалежних вибірок. Аналіз зв'язку між такими категоріальними характеристиками, як вік тварини, локалізація проби, кластер, до якого належить ця проба, здійснювався з допомогою критерію Хі-квадрат незалежності. Кожного разу, коли p-value < 0,05, стверджуємо про наявність зв'язку. Використовували процедуру chi-test програмного середовища статистичних обчислень [7]. На наявність зв'язку між належністю гепатоцитів до виділених кластерів та їі локалізацією в печінковій часточці вказуе Pearson's Chi-squared test $(\mathrm{p}<0,05)$.

Показники, величини, параметри як у тексті, так і в таблицях подані таким чином: М - вибіркове середнє, m - стандартна похибка (відхилення) середнього, $\mathrm{n}$ - об'єм вибірки, p - досягнутий рівень статистичної вірогідності.

Комп'ютерне опрацювання всіх інших параметрів та даних проводилося за допомогою пакету статистичного аналізу STATISTICA (StatSoft, Inc. (2010), STATISTICA (data analysis software system), version 10 . www.statsoft.com).

\section{РЕЗУЛЬТАТИ ТА ЇХ ОБГОВОРЕННЯ}

При дослідженні гістологічних препаратів печінки контрольної групи 12 -ти місячних щурів, як і в людини, у полігональній часточці розрізняють три зони: центральну (III зона), яка містить гепатоцити, розташовані навколо центральної вени; периферичну (І зона), яка знаходиться біля ворітної тріади, та проміжну (II зона), яка локалізуеться між ними. На гістологічних зрізах, забарвлених за Шабадашем, цитоплазма гепатоцитів III-ї зони містить найбільшу кількість глікогену. При цьому, гранули останнього розташовуються по всій цитоплазмі клітини у вигляді скупчень, а гепатоцити I зони містять значно меншу кількість гранул глікогену, які візуалізуються в периферійних відділах цитоплазми.

Аналізуючи гістологічні мікрофотограdiï, ми побачили, що в печінковій часточці за ходом печінкової пластинки від центральної вени до ворітної тріади гепатоцити є різними за площею ядер та площею клітин. Враховуючи це, нами було прийняте рішення виконати кількісний аналіз гепатоцитів різних зон печінкової частки з ура- хуванням морфометрії тільки одноядерних клітин. Проаналізувавши дані дослідження для чистоти експерименту спочатку було здійснено аналіз викидів за допомогою пакету mvoutlier програмного середовища $\mathrm{R}$ (рис. 1). Методом ієрархічної деревоподібної кластеризації Варда отримано дендрограму, та на відстані 100 вибрано 3 кластери (С) клітин для аналізу (рис. 2).

Гепатоцити С1 мають найбільшу площу клітини і ядра та мале ЯЦС, а С3 - характеризуються малою площею клітини, великою площею ядра та найбільшим ЯЦС (табл. 1, рис. 3). Гепатоцити С2 - це середні за площею клітини 3 малим ядром та малим ЯЦС (див. табл. 1, рис. 3).

Попарне співвідношення показало, що кластери статистично вірогідно відрізняються між собою за площею гепатоцитів та їхніх ядер. Тільки співвідношення ЯЦС у С1 та С2 вірогідно не відрізняється (див. табл. 1). Одержані кластери при цьому не перекриваються між собою, що вказує на правильність вибраної характеристики під час їхнього розподілу (рис. 4). 

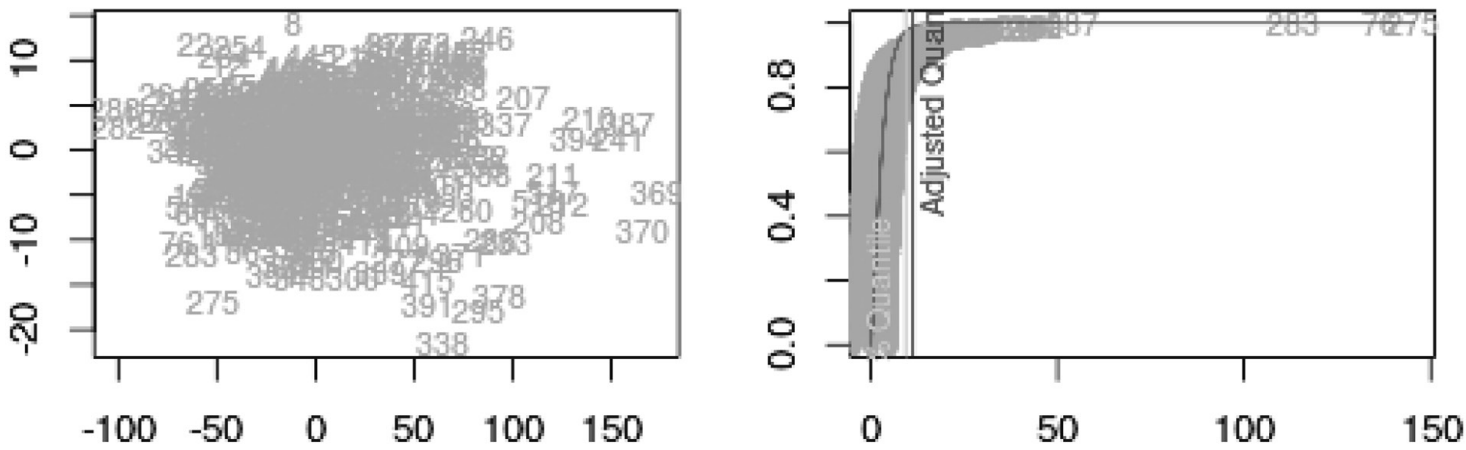

Ordered squared robust distance

Outliers based on $97.5 \%$ quantil Outliers based on adjusted quan
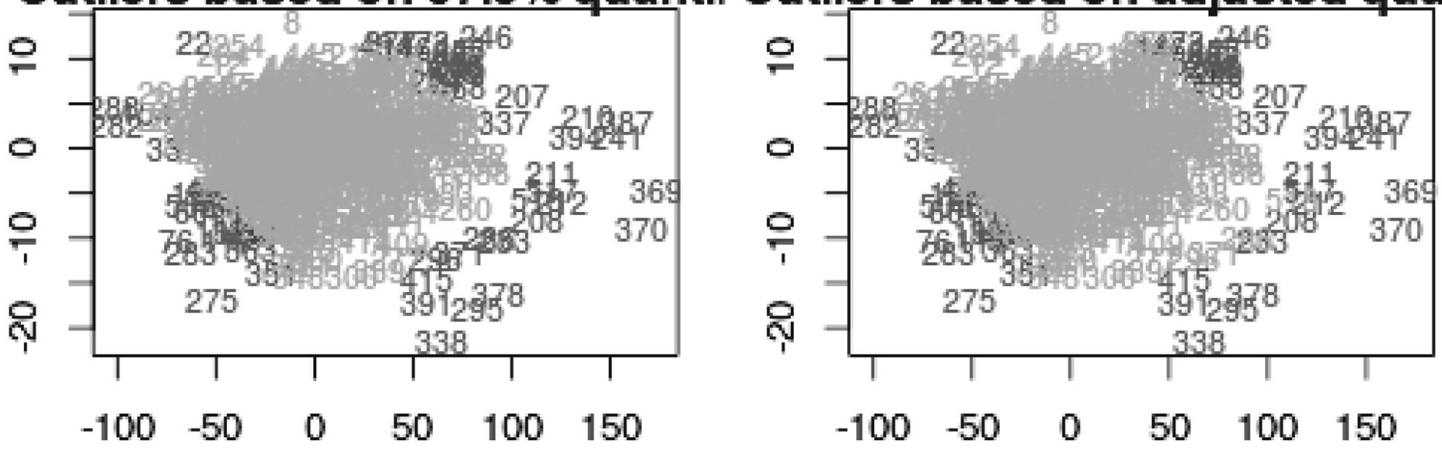

Рис. 1. Аналіз викидів сукупних даних, що не попадають у вибірку та розміщені надто далеко від центру

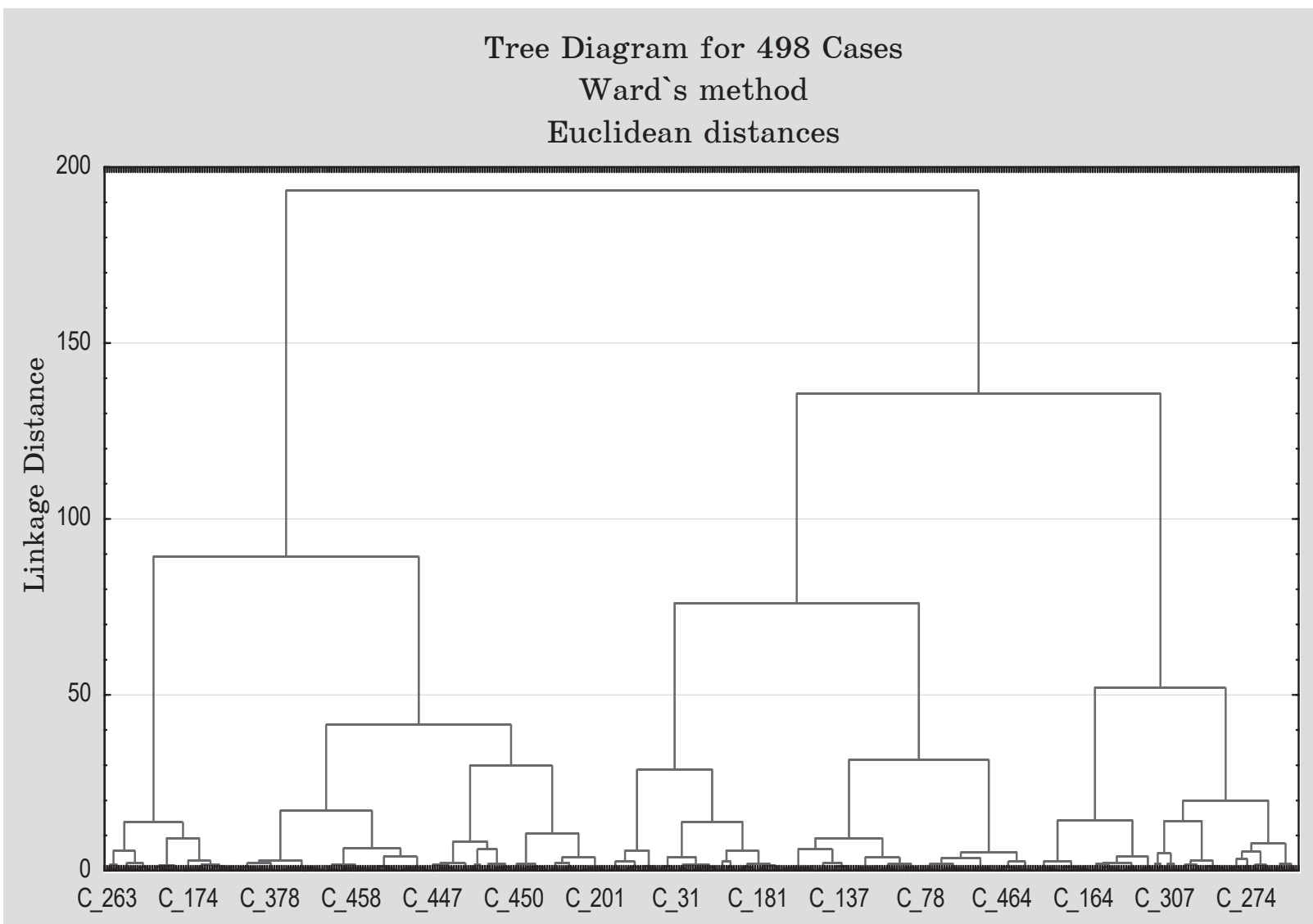

Рис. 2. Дендрограма сукупності гепатоцитів часточки печінки 12 -ти місячних щура (метод деревоподібної кластеризації Варда) 
Описові характеристики кластерів гепатоцитів 12-місячних щурів

\begin{tabular}{c|c|c|c}
\hline Кластери & $\begin{array}{c}\text { Площа гепатоцитів } \\
\left(\mathbf{( м к M}^{\mathbf{2}}\right)\end{array}$ & $\begin{array}{c}\text { Площа ядер гепатоцитів } \\
\left(\mathbf{м к м}^{\mathbf{2}}\right)\end{array}$ & ЯцС \\
\hline $\mathrm{C} 1$ & $291,45 \pm 42,95^{* \S}$ & $56,23 \pm 8,28^{* \S}$ & $0,25 \pm 0,05^{\S}$ \\
\hline $\mathrm{C} 2$ & $217,65 \pm 34,51^{* \#}$ & $39,83 \pm 6,01^{*}$ & $0,23 \pm 0,03^{\#}$ \\
\hline $\mathrm{C} 3$ & $173,79 \pm 35,96^{\# \S}$ & $44,02 \pm 8,81^{\S}$ & $0,34 \pm 0,05^{\# \S}$ \\
\hline
\end{tabular}

Примітки:

* вірогідна різниця між C1 і C2, p < 0,05;

\# вірогідна різниця між C2 і C3, p < 0,05;

$\S$ вірогідна різниця між C1 i C3, p < 0,05.

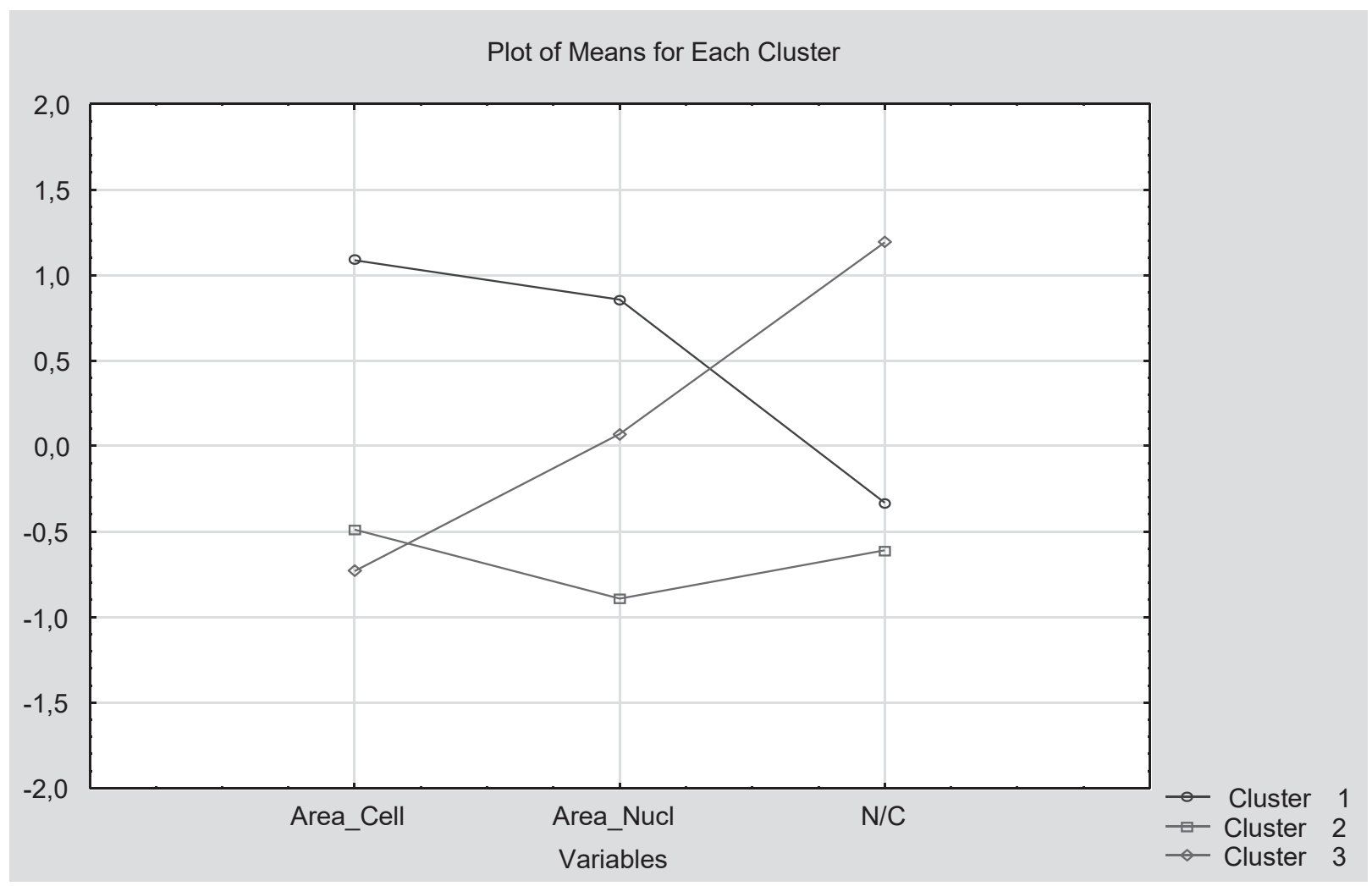

Рис. 3. Графік внутрішньокластерних середніх значень стандартизованих характеристик гепатоцитів контрольної групи тварин.

Примітки:

Area Cell. - площа гепатоцита,

Area Nucl. - площа ядра гепатоцита,

N/C - ядерно-цитоплазматичне співвідношення.

Враховуючи зони, у яких проводились виміри клітин, ми проаналізували вміст кластерів у них, перевіривши гіпотезу про наявність зв'язків за допомогою критерію Хі-квадрат незалежності.

Використовували процедуру chi-test програмного середовища статистичних обчислень R. Pearson's Chi-squared test $(\mathrm{p}<0,05)$ показано, що є зв'язок між належністю клітини до виділених кластерів та її локаліза- ціею в печінковій часточці. На основі аналізу вмісту кластерів гепатоцитів у класичній печінковій часточці встановлено, що найбільша частка припадае на С3 (45,68 \%), а найменша на С1 (21,62 \%), С2 становить $32,71 \%$.

При цьому, виявлено, що гепатоцити С 1 локалізуються переважно в периферичній зоні, С2 і С3 переважають у центральній зоні, а також проміжній (табл. 2). 

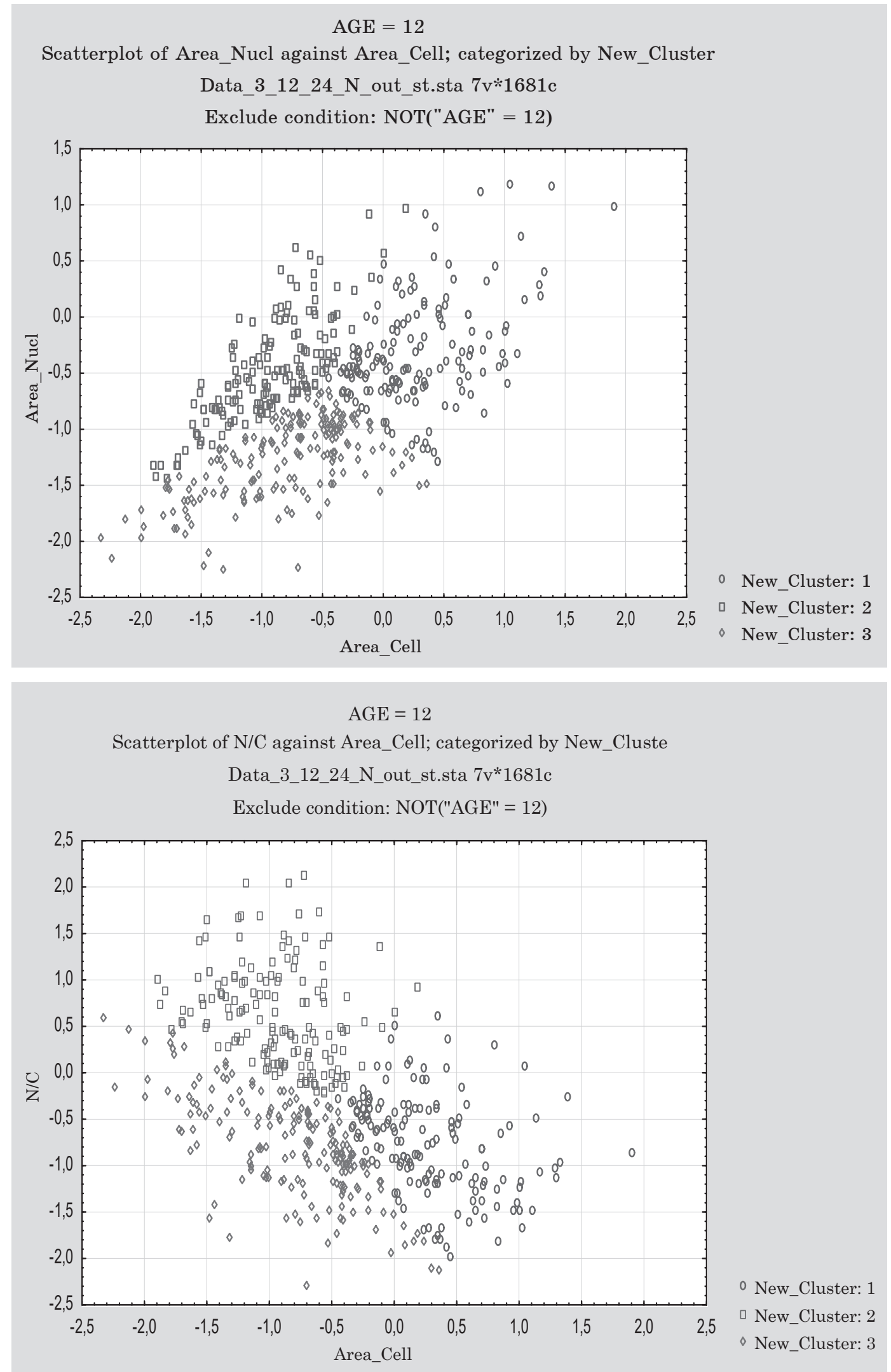

Рис. 4. Струкурний розподіл кластерів відносно площі ядра та площі клітини (а), площі клітини до ЯЦС (б) у контрольної групи тварин.

Примітки:

Area Cell. - площа гепатоцита,

Area Nucl. - площа ядра гепатоцита,

N/C — ядерно-цитоплазматичне співвідношення. 
Спряженість частот відносно локалізації кластеру клітин у класичній печінковій часточці 12-місячних щурів, \%

\begin{tabular}{c|c|c|c}
\hline Зони печінкової часточки & $\mathbf{C ~} \mathbf{~}$ & $\mathbf{C ~} \mathbf{2}$ & $\mathbf{C ~ 3}$ \\
\hline Центральна зона & $10,28 \%$ & $42,06 \%$ & $47,66 \%$ \\
\hline Проміжна зона & $23,27 \%$ & $32,70 \%$ & $44,03 \%$ \\
\hline Периферична зона & $35,22 \%$ & $20,13 \%$ & $44,65 \%$ \\
\hline Усі зони & $21,32 \%$ & $32,71 \%$ & $45,68 \%$ \\
\hline
\end{tabular}

Кластерна характеристика гепатоцитів 12-ти місячних щурів

Таблиця 3 У ранні терміни розвитку стрептозотоцинового цукрового діабету, $\mathbf{M} \pm \mathbf{m}$

\begin{tabular}{|c|c|c|c|c|}
\hline $\begin{array}{c}\text { Тип } \\
\text { кластера }\end{array}$ & Група тварин & $\begin{array}{c}\text { Площа } \\
\text { гепатоцита } \\
\left(\text { мкм² }^{2}\right)\end{array}$ & $\begin{array}{c}\text { Площа ядра } \\
\text { гепатоцита } \\
\left(\mathbf{M \kappa м}^{2}\right)\end{array}$ & ЯЦС \\
\hline \multicolumn{5}{|c|}{14 доба } \\
\hline \multirow{2}{*}{$\mathrm{C} 1$} & ЕСЦД & $252,78 \pm 25,61^{*}$ & $55,29 \pm 6,97^{*}$ & $0,26 \pm 0,04$ \\
\hline & контроль & $291,45 \pm 42,99$ & $56,23 \pm 8,28$ & $0,25 \pm 0,05$ \\
\hline \multirow{2}{*}{$\mathrm{C} 2$} & ЕСЦД & $185,78 \pm 23,77^{*}$ & $35,88 \pm 4,37 *$ & $0,24 \pm 0,03$ \\
\hline & контроль & $217,65 \pm 34,51$ & $39,83 \pm 6,01$ & $0,23 \pm 0,03$ \\
\hline \multirow{2}{*}{ C3 } & ЕСЦД & $175,45 \pm 25,43$ & $44,37 \pm 6,21$ & $0,34 \pm 0,03$ \\
\hline & контроль & $173,79 \pm 35,96$ & $44,02 \pm 8,81$ & $0,34 \pm 0,05$ \\
\hline \multicolumn{5}{|c|}{28 доба } \\
\hline \multirow{2}{*}{$\mathrm{C} 1$} & ЕСЦД & $193,07 \pm 31,49^{* \#}$ & $39,76 \pm 4,87^{* \#}$ & $0,27 \pm 0,07$ *\# \\
\hline & контроль & $290,32 \pm 39,87$ & $55,04 \pm 8,54$ & $0,24 \pm 0,05$ \\
\hline \multirow{2}{*}{$\mathrm{C} 2$} & ЕСЦД & $149,02 \pm 24,83^{* \#}$ & $26,57 \pm 3,78^{* \#}$ & $0,23 \pm 0,04^{\#}$ \\
\hline & контроль & $218,14 \pm 34,51$ & $39,47 \pm 6,01$ & $0,23 \pm 0,03$ \\
\hline \multirow{2}{*}{ C3 } & ЕСЦД & $109,73 \pm 17,09 * \#$ & $28,19 \pm 5,14^{\#}$ & $0,35 \pm 0,06$ \\
\hline & контроль & $171,35 \pm 36,18$ & $43,37 \pm 8,74$ & $0,34 \pm 0,04$ \\
\hline
\end{tabular}

\section{Примітки:}

* вірогідна різниця порівняно з контролем, $\mathrm{p}<0,05$;

\# вірогідна різниця порівняно з попереднім терміном експерименту, $\mathrm{p}<0,05$.

На ультраструктурному рівні також виявлено особливості будови гепатоцитів різних зон контрольної групи щурів. Так, гепатоцити центральної зони мають добре розвинені цистерни АГЕС і велику кількість гранул глікогену, що розсіяні по всій цитоплазмі клітини. Наші дані підтверджуються і даними інших дослідників, які припускають, що в цих клітинах відбуваеться гліколіз [8], а також гепатоцити центральної зони експресують цитоплазматичний і ядерний 8 -катенін, який регулюе експресію таких генів, як глутамінсинтетаза і ферменти цитохрому Р450. Деякі науковці вказують на те, що АГЕС бере участь у синтезі глікогену та детоксикації речовин через цитохром Р-450-залежну систему монооксигеназ [9, 10]. За даними наших досліджень, гепатоцити периферійної зони містять багато мітохондрій, глікогену і численні цистерни ГЕС. Остання бере участь у синтезі фібриногену, плазмопротеїнів, альбумінів, глобулінів та інших білків плазми крові, на що вказують ряд науковців [11].

У ранні терміни розвитку ЕСЦД (1428 доби) рівень глюкози і HbA1с у крові 12-міс. тварин зростае відповідно до 14,35 \pm 0,51 ммоль/л (контроль - 4,64 $\pm 0,39$ ммоль/л, $\mathrm{p}=0,0036)$ та $15,99 \pm 0,48$ ммоль/л (конт- 

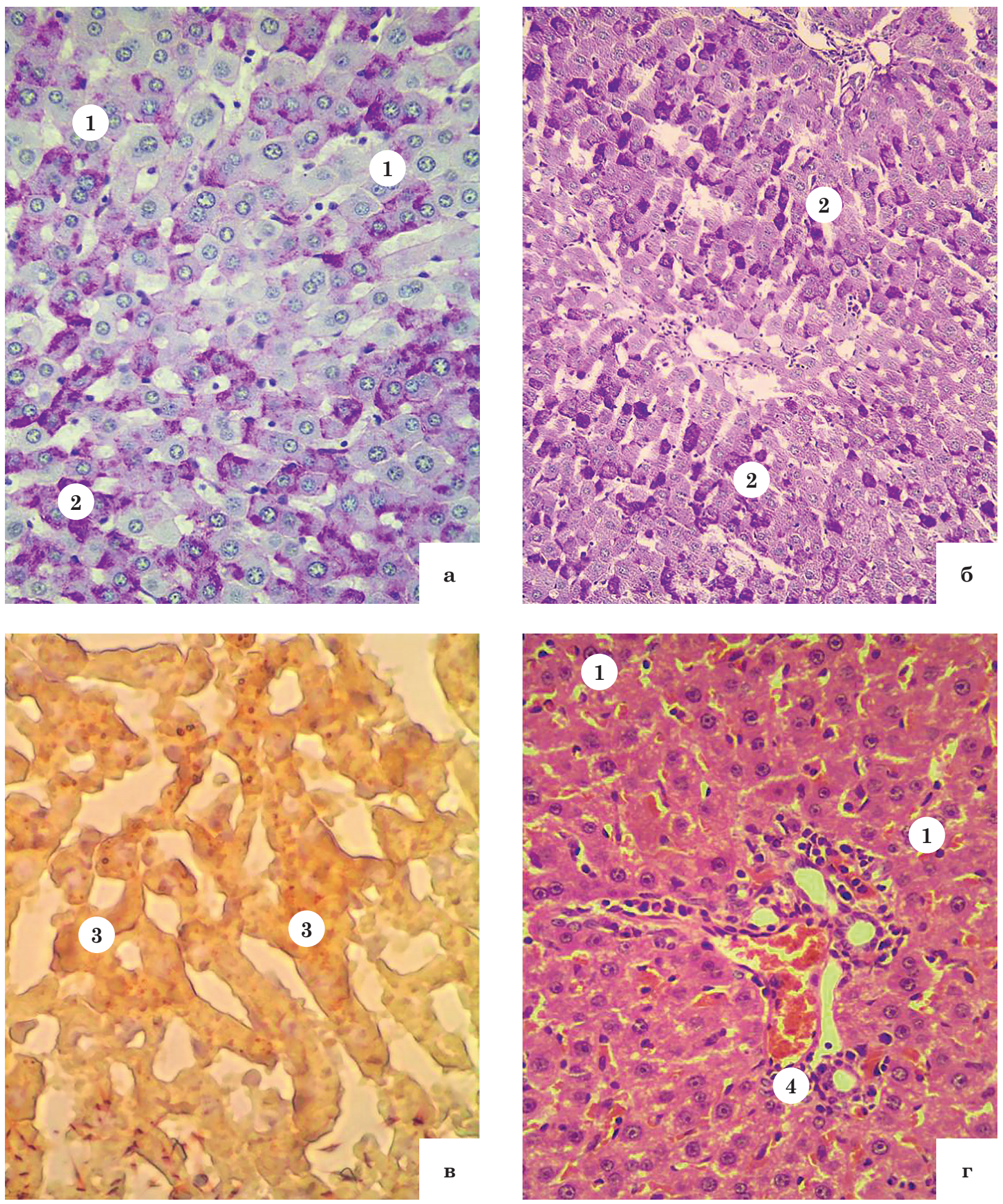

Рис. 5. Зростання чисельності двоядерних гепатоцитів (а)

та ліпідних крапель (в) у них, лімфо-плазмоцитарна інфільтрація

портальних трактів (г) у 24-міс. щурів і зменшення включень глікогену

в периферійній зоні печінкової часточки (б) 12 -ти місячних щурів на 28 добу розвитку ЕСЦД.

Забарвлення: за Шабадашем (а, б), суданом III (в), за Массоном (г). Мікрофротографії. Зб.: $\mathrm{a}-\Gamma) \times 400$.

Позначення:

1 - двоядерні гепатоцити,

2 - гранули глікогену,

3 - ліпідні краплі,

4 - лімфоцитарна інфільтрація портальних трактів,

5 - тріада печінки. 
роль - 4,63 \pm 0,39 ммоль/л, $\mathrm{p}=0,0001)$, $7,03 \pm 0,47 \%$ (контроль - 2,34 \pm 0,19\%, $\mathrm{p}=0,0325)$ та $8,33 \pm 0,32 \%$ (контроль $2,33 \pm 0,1 \%, \mathrm{p}=0,0236)$, що вказуе на розвиток ЦД середнього ступеня важкості.

На 14-28 добу ЕСЦД простежується значна кількість двоядерних гепатоцитів (рис. 5 а) та збільшення ліпідних крапель в окремих гепатоцитах різних зон (рис. 5 в), спостерігається лейкоцитарна інфільтрація портальних тріад часточок печінки (рис. 5 г). Суттєве зменшення кількості гранул глікогену в гепатоцитах (рис. 5 а-б) призводить до просвітлення їхньої цитоплазми. При цьому слід зазначити, що найбільше глікогену втрачають гепатоцити центральної і периферичної зон, натомість гепатоцити проміжної зони містять глікоген. Простежуються розширені центральні вени, синусоїдні капіляри, навколосинусоїдні простори.

Така якісна гістологічна перебудова гепатоцитів призводить до змін їніх кількісних параметрів. За даними морфометричного аналізу, спостерігається зменшення площі гепатоцитів C1 і C2 відповідно на $13,3-33,5 \%$ та $14,6-31,7 \%$ (табл. 3). Натомість гепатоцити С3 не змінюють своїх морфометричних характеристик на 14 добу ЕСЦД, натомість на 28 - вірогідно зменшуються (див. табл. 3). На 28 добу ЕСЦД в усіх кластерах достовірно зменшуеться площа ядра та площа клітин, порівняно з попереднім терміном експерименту та 3 контролем (див. табл. 3). Це може бути проявом того, що в гепатоцитах практично відсутніми є включення гранул глікогену, а також, посиленого виведення його гепатоцитами, тобто втрата глікогеннакопичувальної функції. Щодо ЯЦС, то С2 практично не змінюеться, С3 дещо зростає, С1 зменшується i, як правило, є ознакою зменшення функціональної активності цього кластера гепатоцитів.

Зміни кількісних показників гепатоцитів призводять до перерозподілу відсоткового вмісту різних кластерів гепатоцитів у печігковій часточці. На 14 добу ЕСЦД кількість гепатоцитів С1 зменшується до 18,39\% (контроль - 22,02\%, p < 0,05), тоді як у C2 зростає до $36,45 \%$ (контроль - 31,08\%, p < 0,05), а в С3 не змінюеться і становить 45,16\% (контроль - 46,9\%, p > 0,05). На 28 добу розвитку ЕСЦД кількість гепатоцитів у С1 достовірно не змінюеться і становить 20,7\% (контроль - 21,82\%, p < 0,05), натомість у С2 зменшуеться до $28,39 \%$ (контроль - 32,08\%, p < 0,05), а в С3 зростає до 50,91\% (контроль - 46,1\%, р < 0,05). На нашу думку, зростання клітин С3 є компенсаторною реакцією, оскільки клітини цього кластера переважають у центральній зоні, їхньою основною функцією є дезінтоксикаційна [11], а також вони є основним пулом для утворення молодих гепатоцитів $[12,13]$.

У ранні терміни ЕСЦД на електронномікроскопічному рівні характерним є зменшення кількості гранул глікогену в гепатоцитах. Підтвердженням цього є «запустівання» гепатоцитів, або так звані «глікогенові пустоти» (рис. 6 а, в), які спостерігаються в навколоядерному просторі, де не візуалізуються жодні внутрішньоклітинні органели. Ядра гепатоцитів мають сферичну форму, хроматин конденсований у вигляді грудок уздовж внутрішньої поверхні ядерної оболонки. Остання має нерівні контури за рахунок інвагінацій. Кількість мітохондрій є зменшеною, іхні кристи дезорганізовані і вкорочені, подекуди зазнаючи лізису, матрикс просвітлений. Простежуеться редукція та вкорочення мікроворсинок гепатоцитів як навколосинусоїдного полюса, так і повернутого в сторону жовчного капіляра. Посилюються зміни і в гепатоцитах центральної зони, зокрема С3. З’являються гепатоцити підвищеної електронно-оптичної щільності з великою кількістю деструктивно змінених мітохондрій, редукцією комплексу Гольджі, гранулярної (ГЕС) і гладкої ендоплазматичних сіток, збільшеними ліпідними краплями (рис. 6 б). Поряд із гепатоцитами 3 вакуольною дистрофією візуалізуються гепатоцити, структура яких не відрізняеться від контрольної групи щурів (рис. 6 г).

Такі ультраструктурні зміни гепатоцитів, а саме: зменшення електроннооптичної щільності каріоплазми, збільшення чисельності деструктивно змінених мітохондрій із лізисом їхніх крист, розширення і руй- 

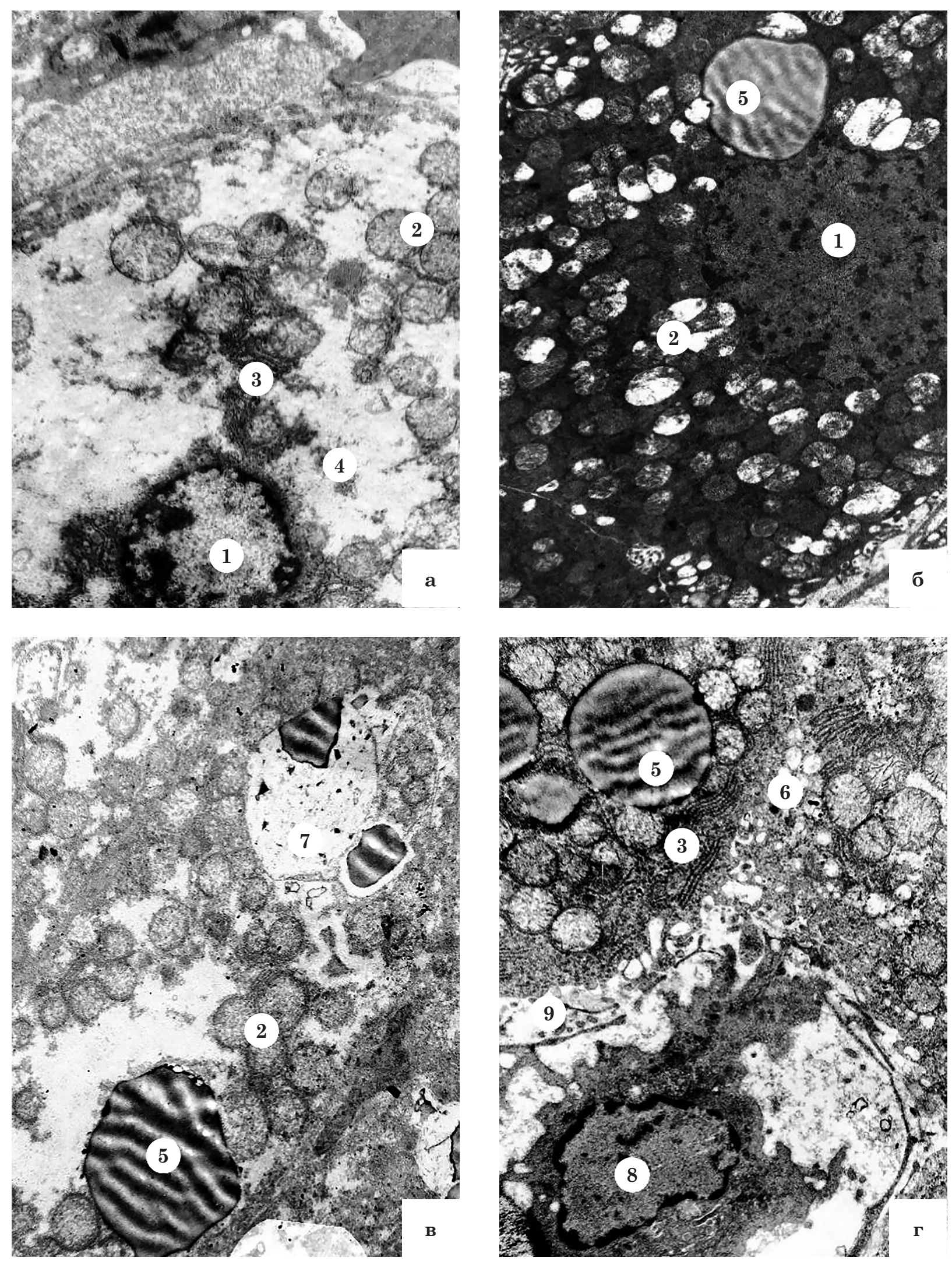

Рис. 6. Наявність голих полів цитоплазми без глікогену у світлих (а, в)

та деструктивні зміни мітохондрій темних (б) гепатоцитів 12 -ти місячних щурів на 28 добу

розвитку ЕСЦД. Електронні мікрофотографії. Зб.: а) × 6400, б) × 4800 .

Позначення:

1 - ядро гепатоцита, 2 - мітохондрії, 3 - ГЕС, 4 - безглікогенові пустоти, 5 - ліпідна крапля,

6 - гладка ендоплазматична сітка, 7 - вакуоля, 8 - ядро зірчастого макрофагоцита, 9 - простір Діссе. 
Активність амінотрансфераз в сироватці крові та гомогенатах печінки при стрептозотоциновому цукровому діабеті, $\mathrm{M} \pm \mathrm{m}$

\begin{tabular}{|c|c|c|c|c|c|c|}
\hline \multicolumn{2}{|c|}{$\begin{array}{c}\text { Термін } \\
\text { проведення } \\
\text { експерименту }\end{array}$} & $\begin{array}{c}\text { АЛТ } \\
\text { (мкмоль/ } \\
(\text { год } \times \text { мл)), } \\
\text { сироватка } \\
\text { крові }\end{array}$ & $\begin{array}{c}\text { АЛТ } \\
(\text { мкмоль/ } \\
(\text { год } \times \text { г)), } \\
\text { гомогенат }\end{array}$ & $\begin{array}{c}\text { АСТ } \\
\text { мкмоль/ } \\
(г о д \times \text { мл) } \\
\text { сироватка } \\
\text { крові }\end{array}$ & $\begin{array}{c}\text { АСТ } \\
(\text { мкмоль/ } \\
(\text { год } \times \text { г)), } \\
\text { Гомогенат }\end{array}$ & $\begin{array}{c}\text { Коефіцієнт } \\
\text { де Рітіса }\end{array}$ \\
\hline \multicolumn{7}{|c|}{ 12-ліс шуури } \\
\hline \multirow{2}{*}{14 доба } & ЕСЦД & $0,99 \pm 0,13^{*}$ & $26,31 \pm 2,02^{*}$ & $1,12 \pm 0,14^{*}$ & $29,51 \pm 2,22 *$ & $1,13 \pm 0,04$ \\
\hline & Контроль & $0,39 \pm 0,02$ & $20,43 \pm 1,13$ & $0,47 \pm 0,02$ & $21,11 \pm 8,01$ & $1,21 \pm 0,04$ \\
\hline \multirow{2}{*}{28 доба } & ЕСЦД & $1,45 \pm 0,05^{*} \#$ & $31,72 \pm 9,01^{*} \#$ & $1,83 \pm 0,11^{*} \#$ & $29,09 \pm 1,83^{*}$ & $1,26 \pm 0,05 \#$ \\
\hline & Контроль & $0,41 \pm 0,02$ & $20,51 \pm 0,82$ & $0,49 \pm 0,02$ & $21,22 \pm 7,04$ & $1,2 \pm 0,01$ \\
\hline
\end{tabular}

Примітки:

* достовірна різниця порівнянно з контролем, $\mathrm{p}<0,05$;

\# достовірна різниця порівняно з попереднім терміном експерименту, p < 0,05.

нування цистерн ГЕС вказують на зменшення енергетичного забезпечення гепатоцитів та пригнічення їхньої метаболічної активності через зниження інсуліну і глюкагону [13]. За даними цих авторів, обидва гормони стимулюють у гепатоцитах синтез РНК і білка. Тому зменшення площі ядер і редукція ГЕС е одніею з ознак пригнічення білоксинтезуючої функції гепатоцитів. Проте у 12 -ти місячних тварин у ранні терміни ЕСЦД спостерігається достовірне підвищення активності амінотрансфераз порівняно з контрольною групою (табл. 4), проте коефіціент де Рітіса статистично значуще не відрізняеться від контрольних показників, що вказуе на розвиток компенсаторних процесів у печінці та збереження повною мірою її функціональної здатності.
Слід зазначити, що найбільш виражене зменшення площі гепатоцитів простежуеться у C1 i C3. Такі зміни можна трактувати тим, що, за даними різних авторів [11], саме гепатоцити периферійної зони є першими, які реагують на метаболічні зміни крові, тому у відповідь на гіперглікемію і гіпоінсулінемію активуються процеси глюконеогенезу, які і призводять до зменшення їхньої площі, за даними наших досліджень. Натомість гепатоцити С3 є депо глікогену і зменшення їхньої площі відбувається з 28 доби експерименту, коли гепатоцити С1 не містять глікогену для забезпечення процесів глюконеогенезу.

\section{ВИСНОВКИ}

1. У ранні терміни розвитку ЕСЦД (14-28 доба) простежуються закономірні зміни морфометричних параметрів гепатоцитів різних кластерів, а саме: зменшення площі гепатоцитів, пов'язане з вираженими процесами глікогенолізу, що підтверджуеться даними гістологічних та ультраструктурних досліджень.

2. Зміни кількісних показників гепатоцитів призводять до перерозподілу відсоткового вмісту різних кластерів гепатоцитів, a саме, зменшення кількості клітин С1, які є депо глікогену в печінковій часточці і зростання клітин С3, які переважа- ють у центральній зоні, і є основним пулом для утворення молодих гепатоцитів.

3. Кількісна і якісна перебудова клітинного складу печінкової часточки вказуе на розвиток компенсаторних процесів у печінці та збереження повною мірою іï функціональної здатності що підтверджуеться і біохімічними змінами, а саме: достовірне підвищення активності амінотрасфераз у плазмі крові та гомогенатах печінки, порівняно з контрольною групою, проте коефіцієнт де Рітіса статистично значуще не відрізняється від контрольних показників. 


\section{ЛITEPATУРА \\ (REFERENCES)}

1. Chudhary D, Cleveland DA, Agdere L, et al. Pediatrics 2018; 141(1): 122-128.

2. Upadhyay R. Hepatology. The Association of Physicians of India-Medicine Update 2017; 67: 314-318.

3. Kumar R. Indian J Endocr Metab 2018; 22: 552-559.

4. Sogujko JuR, Kryvko JuJa. Eksperym klin fiziol biohim 2010; 4: 12-19.

5. Lucchesi AN, Cassettari LL, Spadella CT. J Diab Res 2015; 142: 1-11. doi: 10.1155/2015/494578.

6. Yangen S, Petpiboolthai, Khimmakthong, Anupunpisit V. J Med Assoc Thai 2016; 99(8): 118-129.

7. Liao M, Li Yu, Kianifard F, Obi E, Arcona S. BMC Nephrology 2016; 17(25): 1-15.
8. Berndt N, Holzhütter HG. Front Physiol 2018; 12: 1786. doi: 10.3389/fphys.2018.01786

9. Stanger BZ. Cell Research 2015; 25(11): 1181-1182. doi: 10.1038/cr.2015.117

10. Yang J, Mowry LE, Nejak-Bowen KN, et al. Hepatology. Author manuscript 2014; 60(3): 964-976. doi: 10.1002/ hep. 27082

11. Colnot S, Peret C. Mol Pathol Library 2011; 13: 7-16. doi: 10.1007/978-1-4419-7107-4_2

12. Abdollahi M, Zuki AB, Goh YM. Afr J Biotechnol 2010; 9: 5004-5012.

13. Noorafshan A, Esmail-Zadeh B, Bahmanpour S, PoostPasand A. Indian J Gastroenterol 2005; 24(3): 104-117.

\section{MORPHO-FUNCTIONAL CHARACTERISTICS LIVER OF RATS IN EARLY DEVELOPMENT OF STREPTOSOTOCIN DIABETES MELLITUS USING CLUSTER ANALYSIS}

Zhurakivska O. Ya., Bodnarchuk Yu. V., Kostitska I. O., Kindrativ E. O., Andriiv A. V., Zhurakivskyi V. M., Miskiv V. A., Pertsovych V. M., Sahan N. T., Ivantsiv O. R.

Ivano-Frankivsk National Medical University Ministry of Health Care of Ukraine,

Ivano-Frankivsk, Ukraine

zhurakivska.o.ya@gmail.com

One of the complications of diabetes mellitus (DM) is diabetic hepatopathy which, according to various authors, is diagnosed in $33-88 \%$ of patients. Therefore, the aim of our study was to establish the features of morphofunctional changes in the liver of 12 -month rats at experimental streptozotocin-induced diabetes mellitus (ESDM) using cluster analysis. Used histological, histochemical, electron microscopic, biochemical and statistical research methods.

Analyzing histological microphotographs, we saw that in the hepatic lobe along the liver plate are hepatocytes, which are different in size of cells and nuclei. Therefore, we performed a quantitative analysis of hepatocytes in different areas of the liver lobe, taking into account the morphometry of only mononuclear cells. Using the mvoutlier package of the software environment $\mathrm{R}$ and the method of hierarchical tree-like clustering of Ward, 3 clusters (C) of cells were selected for analysis. In the control group of rats were found hepatocytes C1 which have the largest cell and nucleus area and a small nuclear-cytoplasmic ratio (NCR), and hepatocytes C3 was characterized by a small cell area, a large nucleus area and the largest NCR, C2 - medium-sized cells with a small nucleus and small NCR. The largest number of hepatocytes is C3 (45.68\%), and the smallest - C1 $(21.62 \%), \mathrm{C} 2-32.71 \%$. It was found that hepatocytes $\mathrm{C} 1$ are located mainly in the peripheral zone of the liver, $\mathrm{C} 2$ and $\mathrm{C} 3$ are located in the central and intermediate zone.

In the early stages of the development of ESDM (14-28 days), the levels of glucose and HbA1c in the blood of animals significantly increase 3.1-3.4 times and 3.0-3.6 times (in all cases p < 0.05). In animals we observed regular changes in the morphometric parameters of hepatocytes of different clusters (C), namely: there was a decrease in the area of hepatocytes, which is associated with marked processes of glycogenolysis, that are confirmed by histological and ultrastructural studies. The area of nuclei of hepatocytes of different clusters decreases (in all cases $\mathrm{p}<0.05$ ). On the 14th day of ESDM the number of hepatocytes in $\mathrm{C} 1$ decreased by $3.64 \%$, while in $\mathrm{C} 2$ it increases by $5.37 \%$, while on the 28 th day in $\mathrm{C} 2$ it decreases by $3.69 \%$, while in C3 it increases by $4.81 \%$ (in all cases $\mathrm{p}<0.05$ ), indicating an increase in the pool of young hepatocytes and compensatoryregenerative processes of the liver.

In the early stages of ESDM, there is a significant increase in the activity of aminotransferases in both plasma and liver homogenates, as compared with the control group, but the De Ritis ratio does not statistically differ from the control indicators, showing the development of compensatory processes in the liver and preserving its complete functional capacity.

Key words: liver, hepatocyte, streptozotocin-induced diabetes mellitus. 


\section{МОРФОФУНКЦІОНАЛЬНА ХАРАКТЕРИСТИКА ПЕЧІНКИ ЩУРІВ У РАННІ ТЕРМІНИ РОЗВИТКУ СТРЕПТОЗОТОЦИНОВОГО ЦУКРОВОГО ДІАБЕТУ З ВИКОРИСТАННЯМ КЛАСТЕРНОГО АНАЛІЗУ}

Жураківська О. Я., Боднарчук Ю. В., Костіцька І. О., Кіндратів Е. О., Андріїв А. В., Жураківський В. М., Міськів В. А., Перцович В. М., Саган Н. Т., Іванців О. Р.

Івано-Франківський національний медичний університет, м. Івано-Франківськ, Украӥна

zhurakivska.o.ya@gmail.com

Одним із ускладнень цукрового діабету (ЦД) є діабетична гепатопатія, яка, за даними різних авторів, діагностуеться у 33-88\% хворих. Тому метою нашого дослідження було встановити особливості морфофункціональних змін печінки 12 -ти місячних щурів при експерименальному стрептозотоциновому ЦД (ЕСЦД) з використанням кластерного аналізу. Використали, гістологічний, гістохімічний, електронномікроскопічний, біохімічний та статистичний методи дослідження.

Аналізуючи гістологічні мікрофотографії, ми побачили, що в печінковій часточці за ходом печінкової пластинки розташовуються гепатоцити, які е різними за площею клітин та ядер. Тому ми виконали кількісний аналіз гепатоцитів різних зон печінкової частки з урахуванням морфометрії тільки одноядерних клітин. За допомогою пакету mvoutlier програмного середовища $\mathrm{R}$ та методом ієрархічної деревоподібної кластеризації Варда вибрано 3 кластери (C) клітин для аналізу. У контрольної групи щурів встановлено, що гепатоцити С1 мають найбільшу площу клітини і ядра та мале ядерно-цитоплазматичне співвідношення (ЯЦС), а С3 - характеризуються малою площею клітини, великою площею ядра та найбільшим ЯЦС, С2 - це середні за площею клітини з малим ядром та малим ЯЦС. При цьому найбільше гепатоцитів е С3 (45,68\%), а найменше - C1 (21,62\%), С2 становить 32,71\%. Виявлено, що гепатоцити С1 локалізуються переважно в периферичній зоні печінкової часточки, С2 і С3 переважають у центральній зоні і проміжній.

У ранні терміни розвитку ЕСЦД (14-28 доба) рівень глюкози і НbA1c у крові тварин достовірно зростає відповідно в 3,1-3,4 раза та в 3,0-3,6 раза (у всіх випадках $\mathrm{p}<0,05$ ). У тварин простежуються закономірні зміни морфометричних параметрів гепатоцитів різних кластерів (С), а саме: зменшення площі гепатоцитів пов'язане з вираженими процесами глікогенолізу, що підтверджується даними гістологічних та ультраструктурних досліджень. При цьому площа ядер гепатоцитів різних кластерів, порівняно $з$ контролем, зменшуеться (у всіх випадках р < 0,05). На 14 добу розвитку ЕСЦД кількість гепатоцитів у С 1 зменшуеться на $3,64 \%$, а в С2 збільшуеться на 5,37\%; на 28 добу - у С2 зменшуеться на $3,69 \%$, а в С3 зростає на 4,81\% (у всіх випадках р < 0,05), що вказуе на збільшення пулу молодих гепатоцитів та на компенсаторно-регенераторні процеси в печінці.

У ранні терміни ЕСЦД спостерігаеться достовірне підвищення активності амінотрасфераз як у плазмі крові, так і гомогенатах печінки, порівняно з контрольною групою, проте коефіціент де Рітіса статистично значуще не відрізняеться від контрольних показників, що вказуе на розвиток компенсаторних процесів у печінці та збереження повною мірою її функціональної здатності.

К л ючов і с лов а : печінка, гепатоцит, стрептозотоциновий цукровий діабет. 